\title{
Teachers' Perceived Factors of Deviant Behavior among Secondary School Students in Kwara State: Implication for Educational Managers
}

\author{
Yusuf Suleiman \\ Unicaf University, Cyprus \\ y.suleiman@unicaf.org \\ https://orcid.org/0000-0002-4740-6839 \\ Jamiu Mahmood Suleiman \\ Kwara State College of Arabic EO Islamic Legal Studies, Nigeria \\ omsjamin@gmail.com \\ Mahmud Aremu Musa \\ Kwara State College of Arabic E Islamic Legal Studies, Nigeria \\ musamahmudcails@yahoo.com \\ Yusuf Abiola Abubakar \\ Kwara State Universal Basic Education Board, Nigeria \\ yusufabiola50@gmail.com
}

\begin{abstract}
This study investigates students' deviant behaviors as perceived by their teachers in secondary schools with the aim of knowing the factors responsible for such behaviors. The study adopts the quantitative approach to carry out the research. Stratified and simple random techniques were used to select 380 participants that participated in the study. An instrument tagged "Factors of Deviant Behaviors and Measures Questionnaire" (FDBMQ) was used to elicit data from the respondents. Partial Least Square (PLS) software was used to assess the psychometric properties of the items contained in the questionnaire, while Statistical Package for Social Sciences (SPSS) was used to do the descriptive analysis. In addition, the analysis of variance (ANOVA) was used to test the three hypotheses formulated for the study. Results of the study revealed three factors (parent, society and school) that contribute to deviant behaviors. Findings also indicate measures that can be used to minimize deviant behaviors. Also, the results of the ANOVA showed a significant difference, while Duncan's Multiple Range Test (DMRT) was used as a post-hoc test to determine the group that
\end{abstract}

Teachers'

Perceived

Factors of

Deviant

Behavior among

Secondary

School Students

in Kwara State:

Implication for

Educational

Managers

\section{Psynergia}

International Journal of Synergy and Research

Vol. 7, 2018 pp. $59-79$ 
IJSR 7 contributes to the significant difference. The results of the three hypotheses confirmed that significant difference exists on the basis of religion, age, and educational qualifications. Based on the findings of the study, implication for educational managers and future research direction were provided.

Keywords - teachers' perception, deviant behavior, educational managers, secondary school, Kwara State

\section{Introduction}

Deviant behavior is seen as any behavior that does not fit in to the established rules of a group of individuals or the society at large (Idris, 2016; Orsati and Causton-Theoharis, 2013; Vieno et al., 2011; Zakaria et al., 2013). Deviant behavior is an activity which conflicts with the societal norms. It can also be described as engagement of people in criminal offences, antisocial and unethical behavior. Deviant behavior could also be any form of behavior that contravenes the rules and regulations or even laws that govern an establishment (Esere, 2008; Dyregrov et al., 2013; Richardson, 2014; Ryan and Shim, 2012). According to Bolu-Steve and Esere (2017), a teenager finds it hard to conform to the customs of the society because he or she is in adolescence stage during which an individual progresses from the point of initial appearance of the secondary sexual characteristics to that of sexual maturity. This period is escorted by various modifications that are significant in intellectual, emotional, physical and social areas. Ibrahim (2009) noted that an adolescent is someone who is unstable, angry, moody, self-conscious and inexperienced in handling emotional problems. Adolescence, from a psychological point of view, is a stage or period dominated by pressures and stress due to inner emotional volatility and as a result of disagreeing external influence.

The demonstration of deviant behavior among students in school, often leads to ineffective teaching and learning. The unruly behavior among students leads to great consequences in their academic pursuit (Ojedokun et al., 2013; Ololube, 2013; Pas and Bradshaw, 2014). Researchers have identified different types of deviant behavior among students in school; these include cultism, stealing, bullying, smoking, raping, examination malpractice, truancy (Esere, 2008; Polanin and Low, 2014). Ponfua (2015) classified types of deviant behavior into three categories; they include cases relating to disobedience to school authority (e.g. assault on and insult to teachers and non-teachers); cases relating to the collective misbehavior of students groups (e.g., vandalism, mass protest and cultism) and cases relating to poor habits (e.g. speaking pidgin English, chewing gum in class, examination malpractice, wearing dirty and wrong uniform, fighting, drug abuse, alcoholism, and idleness).

Generally, deviant behavior is common among youth (irrespective of their age, religion, culture, creed, and sex) and it is seen as a global phenomenon. In Africa, report shows that prevalence of bullying in South African schools ranges from $12 \%$ to $61 \%$. Reported bullying victimization occurrence rates in schools in other African countries are as follows: Botswana 52\%, Ghana 59\%, Kenya 57\%, Mauritius 40\%, Namibia 52\%, Tanzania 28\%, Uganda 46\%, and Zambia 65\%. The foregoing information highlights the pervasive rate of deviant behavior among African adolescents. In Nigeria, it is reported that bullying victimization prevalence is $78 \%$ among junior secondary school students (Owusu et al., 2010). In 2017, primary school pupils in Kaduna protested against the 
sack of 21,780 teachers by the state government (Pulse News, 7 November 2017). The Nation newspaper of 8 August 2017 reported that 30 people were killed in cult clashes among youths in Kwara State, Nigeria.

Idowu (2008) and Ukwayi et al. (2012) reported that peer pressure influenced students to involve in tobacco smoking. Boyd (2015) noted that many students are involved in the use of amphetamines, tobacco barbiturates and heroin. Similarly, Idris (2016) gives details of several cases of cultism, smoking, sexual abuse, destruction, extortion, threats and coercions as reported by school principals. Studies revealed that factors of deviant behavior are yet to be fully explored, which prompts the present study to investigate teachers' perceived factors responsible for deviant behavior in secondary schools in Kwara State.

\section{Literature review}

Several studies have been conducted on deviant behaviors of students as something that is inimical to their educational pursuit. For instance, Espelage et al. (2014) studied on bullying, family violence, alcohol and drugs taking as it influences students' behaviors in the school system. The study employed quantitative approach for the study. The respondents for the study were drawn out from among African and American students in four middle schools in the United State of America. Survey instrument was completed by the participants. The outcome of the study found that family violence influences the male students in the school to engage in deviant behaviors. Also, females who were exposed to family violence and bullying had greater probability of engaging in unwholesome behaviors in the school. The study recommended that future studies should focus on other forms of deviant behaviors among students.

Cluver et al.'s (2010) investigation revealed that internal personal conflict witnessed by children enables them to behave in an immoral way in the school. Research conducted on adolescent misperceives and behaviors among students in the school system demonstrated that associate group generalizations are personifications. The study showed that teenagers misinterpret their peers' high-risk practices, and such an understanding encourage young adolescents to behave in a specific way, related to danger (Efstratopoulou et al., 2012; Helms et al., 2014; Jamiu, 2011; Oyerinde, 2004).

Reid (1999) found that students who come from poor background engaged in truancy in school, while Gray and Jesson (1990) found that students from the single-parent family have a poorer attendance rate than those from the more traditional family. Siziya et al. (2007) reported that some parents rarely checked homework; they neither understood the difficulties and concerns of students nor supervised the students and this often leads to students to engage in situations that are not in line with societal norms. Akseer et al. (2014) focused their study on the perceptions of teachers concerning shyness among male and female students in Canadian elementary schools. In their study, they found that teachers perceived differences in shyness between boys and girls in the classroom. They concurred that shyness is more common among boys than girls. Malak et al. (2014) studied teachers' perception of deviant behaviors of students in Bangladesh schools. Selected teachers were interviewed in order to know their perceived perception of their students in the school system. The above-mentioned authors found that teachers viewed the behaviors as disruptive, aggressive and disrespectful and they were of the opinion that these behaviors of students are unacceptable, intentional and not likely to change.
Teachers'

Perceived

Factors of

Deviant

Behavior among

Secondary

School Students

in Kwara State:

Implication for

Educational

Managers 
IJSR 7
The study concluded that lack of punishment in school and poor parenting could be responsible for the behaviors. The study suggested that measures should be implemented in order to curb these annoying behaviors.

Ponfua (2015) examined the students' indiscipline in secondary schools in Cameroon and found that student-based factor, parent-based factor and school-based factor are causes of students' deviant behavior. Garry (2001), Omoegun (1995), Osarenren (1996) and Owodunni (2008) reported that insufficiencies at home and lack of capacity to make petty cash to augment family income and unfavorable home conditions cause unruly behavior such as truancy. Yarduma and Abdulamid (2007) found that the dynamic explosion of the media system through Facebook, Twitter, LinkedIn, WhatsApp, Imo, YouTube, television, radio, magazines and newspapers as well as computer have contributed to the inculcation of deviant practices among students in school. They noted that some programs which are broadcast on radio and television usually promote violence and pornography among students.

Salami and Aremu (2006) investigated the relationship between problem-solving ability and study behavior among school-going adolescents in south-western Nigeria. They found that deviant conduct starts when students show immoral acts, for example, pickstashing, fleeing from home, group association, involvement in illicit sexual activities and truancy. Estévez et al. (2005) limited their studies to victimization and violent behaviors of students in the school by examining the role of teachers and parents. The results indicated that a victimized student, which is also having a conflict relationship with the parents, affects the psychological problems of such student. The results also suggest that peer victimization leads to psychological depression among students. The study concluded that other behaviors among students should be examined to know whether it will give similar findings or not. Yaroson (2006) reported that unrealistic school rules are the causes of indiscipline and concluded that rules and regulations are meant to guide and control activities in school but when they become too much and unenforceable, they tend to breed indiscipline. Asiyai (2005), Iheanyi and Ikechi (2012), Oyesola (2002) and Rothman (2001) concluded that students' emotional instability and unconducive school environment are responsible for deviant behavior such as truancy in secondary school.

Furthermore, literature on the subject shows that, according to the social learning theory, family and peer relationships exert a significant influence on adolescent alcohol or liquor use as they constitute the primary environment where good and bad morals are learned. Social learning theory postulates that an individual learns to take alcohol or drugs in small and informal groups. Undeniably, it is in these formal groups that adolescents learn favorable or unfavorable behavior of alcohol use. Therefore, the emphasis of many social learning theorists is on peers as a result of the importance which children or adolescents give to their friends as they reach adulthood and gradually gain independence from their parents (Akers, 1998; Akers and Sellers, 2004; Akers and Jensen, 2005). In the same vein, Sigmund Freud's psychological theory suggests that individuals are predisposed to deviant behavior when they are fixed at any stage of development and that human beings have natural drives and compulsions that are stifled in the unconscious. Freud also believed that all human beings have criminal propensities and their behaviors are curbed through the process of socialization. A child that does not socialize properly can develop antisocial behavior instincts and when such deviant attitudes get fixed at any of the psychosocial 
stages, such an individual can engage in deviant behavior. Freud stressed the importance of early years of childhood fixation in defining the adult personality (Omotosho, 2009).

Bolu-Steve and Esere (2017) found that the experience of the counselors differ in terms of an appropriate strategy for managing deviant behavior among in-school adolescents irrespective of their years of service, religion and school type. The gender of the counselor tends to modify the strategies applied in the management of deviant behavior among in-school adolescents. Studies conducted by Ojo (2000) and Sulaiman (2011) examined several strategies that can be used to reduce deviant behaviors in secondary schools. They concluded that students need to be assisted in handling contemporary challenges and that information-based intervention is an effective strategy in handling deviant behavior, so counselors should always provide right information to in-school adolescents about the negative effects of deviant behaviors.

In view of the foregoing studies, the focus of the present study is to investigate teachers' perceived factors of deviant behavior among students in secondary schools.

\section{Research Questions}

1. What are the factors responsible for deviant behavior among students?

2. What are the measures that can be used to reduce deviant behavior among students?

3. Is there any significant difference in perception of deviant behavior based on teachers' religion, age and educational qualification?

\section{Research Objectives}

1. To identify possible factors responsible for deviant behavior among students.

2. To provide measures that can be used to reduce deviant behavior among students.

3. To find out if there is a significant difference in perception of deviant behavior based on teachers' religion, age and educational qualification.

\section{Research Hypotheses}

1. There is no significant difference in teachers' perception of deviant behaviors based on religious affiliation.

2. There is no significant difference in teachers' perception of deviant behaviors based on age.

3. There is no significant difference in teachers' perception of deviant behaviors based on educational qualification.

\section{Materials and methods}

\section{Population/sampling techniques}

The study adopted the descriptive survey research design method. The target population for this study consisted of secondary schools teachers (both public and private). Specifically, 320 teachers were selected (using stratified and simple random techniques) from five secondary schools in the Ilorin metropolis area of Kwara State, Nigeria (Creswell and Clark, 2007; Sekaran and Bougie, 2009).
Teachers'

Perceived

Factors of

Deviant

Behavior among

Secondary

School Students

in Kwara State:

Implication for

Educational

Managers 
IJSR 7

\section{Study instrument}

The instrument adopted for the study is questionnaire entitled "Factors of Deviant Behaviors and Measures Questionnaire" (FDBMQ). The items in the questionnaire were adapted from the work of Iheayi and Ikechi (2012) and Ponfua (2015) to investigate teachers' perceived factors of deviant behavior among students. The respondents to the instrument indicated one response option on a 4-point Likert-type summated rating scale of agreement with assigned values of "Strongly Disagree" (SD) - 1, "Disagree" (D) - 2, "Agree" (A) - 3, and "Strongly Agree" (SA) - 4 in order of agreement. The design of the questionnaire was based on the research questions and hypotheses raised in this study (Creswell, 2009; Sekaran and Bougie, 2009).

\section{Content validity and reliability of the instrument}

Content validity can be defined as a measure of how well a test measures what it supposed to measure. In order to ensure good validity of the adapted instrument, the instrument was given to experts in the field of the study who read through the items and made useful suggestions which were later incorporated into the final copy before administering it to the respondents (Creswell, 2009). In the same vein, reliability refers to the degree to which the items that make up the scale are all measuring the same underlying attribute. Therefore, in order to ensure reliability of the instrument, a pilot study was conducted by using 50 teachers in one of the secondary schools selected study for the main study. The Cronbach's alpha of the pilot study revealed 0.83 for the adapted instrument (Creswell and Clark, 2007; Pallant, 2010).

\section{Data collection and analysis procedure}

In order to increase response rate in this study, we employed two research assistants who assisted us in collecting data. All the questionnaires distributed and administered to the respondents were collected by the researchers (Creswell and Clark, 2007). Both Partial Least Square (PLS) and Statistical Package for Social Sciences (SPSS) were used for data analysis. The PLS software was used to assess the psychometric properties of the instrument, while SPSS was used for the descriptive analysis. Also, the analysis of variance (ANOVA) technique was used to test the three hypotheses formulated, while Duncan's Multiple Range Test was used to determine the direction of significant difference (Creswell and Clark, 2007; Sekaran and Bougie, 2009).

\section{Data analysis}

\section{Response rate}

A total of 380 questionnaires were distributed to teachers in five selected secondary schools located in the Ilorin metropolis area of Kwara State, Nigeria. In order to ensure high response rate, we made several visits to schools, with a view to ensuring high return questionnaires (Pallant, 2010). Out of 380 questionnaires distributed, 342 questionnaires were returned, while 38 were not. Because substantial parts of the questionnaires were not properly filled by the participants, we have a total number of 40 unusable questionnaires, and the remaining 302 duly completed questionnaires were 
Pobrane z czasopisma International Journal of Synergy and Research http://ijsr.journals.umcs.pl

Data: 26/04/2023 17:14:10

used for the analysis. Therefore, $90 \%$ of response rate is considered appropriate for the analysis in this study which is in line with Sekaran and Bougie's (2009) suggestion that a response rate of $30 \%$ and above is good enough for the survey research. Table 1 shows the response rates to the questionnaires.

\begin{tabular}{|c|c|}
\hline Response & Rate \\
\hline Questionnaires distributed & 380 \\
\hline Questionnaires returned & 342 \\
\hline Questionnaires not returned & 38 \\
\hline Invalid questionnaires & 40 \\
\hline Valid questionnaires & 302 \\
\hline Response rate & $90 \%$ \\
\hline
\end{tabular}

Source: Authors' own study.

\section{Respondents' profile}

\begin{tabular}{|c|c|c|c|}
\hline Variable & Category & Frequency & Percentage \\
\hline \multirow{3}{*}{ Gender } & Male & 178 & 59 \\
\hline & Female & 124 & 41 \\
\hline & Total & 302 & 100 \\
\hline \multirow{5}{*}{ Age } & $21-30$ & 8 & 3 \\
\hline & $31-40$ & 230 & 76 \\
\hline & $41-50$ & 36 & 12 \\
\hline & 51 and above & 28 & 9 \\
\hline & Total & 302 & 100 \\
\hline \multirow{3}{*}{ Religion } & Islam & 173 & 57 \\
\hline & Christianity & 129 & 43 \\
\hline & Total & 302 & 100 \\
\hline \multirow{3}{*}{$\begin{array}{l}\text { Academic } \\
\text { qualification }\end{array}$} & NCE and ND & 212 & 70 \\
\hline & BSc, HND and above & 90 & 30 \\
\hline & Total & 302 & 100 \\
\hline \multirow{5}{*}{ Working experience } & Less than 1 year & 35 & 12 \\
\hline & $1-5$ years & 131 & 43 \\
\hline & $6-10$ years & 120 & 40 \\
\hline & 10 and above & 16 & 5 \\
\hline & Total & 302 & 100 \\
\hline
\end{tabular}

Source: Authors' own study.

Table 2 explains the profile of the respondents who participated in the study. The profile includes: gender (male - $178(59 \%)$ and female - $124(41 \%)$ ); age (21-30 (3\%), 31-40 (76\%), 41-50 (12\%), 51 and above (9\%)); religion (Islam - $173(57 \%)$, Christianity - 129 (43\%)); academic qualification (NCE-ND - 212 (70\%), BSc, HND and above $90(30 \%)$ ); and working experience (less than 1 year $-35(12 \%), 1-5$ years $131(43 \%), 6-10$ years $-120(40 \%), 10$ years and above $-16(5 \%))$.
Teachers'

Perceived

Factors of

Deviant

Behavior among

Secondary...

Table 1.

Response rates
Table 2.

Profile of the respondents 
Pobrane z czasopisma International Journal of Synergy and Research http://ijsr.journals.umcs.pl

Data: 26/04/2023 17:14:10

66

IJSR

7

\section{Assessment of psychometric properties of the variables}

The assessment of individual item reliability of the variables is considered necessary for this study so as to know whether items adapted measure what they suppose to measure (Duarte and Raposo, 2010). According to Hair et al. (2012), individual item reliability of the variables can be assessed by examining the outer loadings of each construct's measure. To achieve that, the individual items of the study were assessed by examining the outer loadings of the construct's measure. In line with rule of thumb for retaining items with loadings between .40 and .84 , as recommended by Hair et al. (2012), therefore, the items in this study had loadings between .734 and .987 (see Table 3).

\begin{tabular}{|c|c|c|}
\hline Variable & Code & Loadings \\
\hline \multirow{6}{*}{ Parent Factor (PF) } & PF1 & .801 \\
\hline & PF2 & .987 \\
\hline & PF3 & .851 \\
\hline & PF4 & .818 \\
\hline & PF5 & .897 \\
\hline & PF6 & .866 \\
\hline \multirow{5}{*}{ Societal Factor (SF) } & SF1 & .810 \\
\hline & SF2 & .826 \\
\hline & SF3 & .815 \\
\hline & SF4 & .866 \\
\hline & SF5 & .817 \\
\hline \multirow{11}{*}{ School Factor (SF) } & SF1 & .828 \\
\hline & $\mathrm{SF} 2$ & .834 \\
\hline & SF3 & .812 \\
\hline & SF4 & .844 \\
\hline & SF5 & .821 \\
\hline & SF6 & .872 \\
\hline & SF7 & .734 \\
\hline & SF8 & .831 \\
\hline & SF9 & .846 \\
\hline & SF10 & .789 \\
\hline & SF11 & .811 \\
\hline \multirow{10}{*}{ Reducing Deviant Behavior } & RD1 & .846 \\
\hline & RD2 & .833 \\
\hline & RD3 & .901 \\
\hline & RD4 & .875 \\
\hline & RD5 & .809 \\
\hline & RD6 & .869 \\
\hline & RD7 & .961 \\
\hline & RD8 & .902 \\
\hline & RD9 & .892 \\
\hline & RD10 & .861 \\
\hline
\end{tabular}

Source: Authors' own study.
Table 3.

Item loadings 
Response to Research Questions

Research Question No. 1: What are the factors responsible for deviant behavior among students?

\begin{tabular}{|c|c|c|c|c|c|c|}
\hline & Item & SD & D & A & SA & Remark \\
\hline PF1 & Over pampering of children by parents & - & - & $\begin{array}{c}78 \\
(26 \%) \\
\end{array}$ & $\begin{array}{c}224 \\
(74 \%)\end{array}$ & Agreed \\
\hline PF2 & Rejection of children by parents & $\begin{array}{c}2 \\
(1 \%)\end{array}$ & $\begin{array}{c}8 \\
(3 \%)\end{array}$ & $\begin{array}{c}2 \\
(1 \%)\end{array}$ & $\begin{array}{c}290 \\
(96 \%)\end{array}$ & Agreed \\
\hline PF3 & Parents'separation & $\begin{array}{c}35 \\
(12 \%) \\
\end{array}$ & $\begin{array}{c}5 \\
(2 \%) \\
\end{array}$ & $\begin{array}{c}58 \\
(19 \%) \\
\end{array}$ & $\begin{array}{c}204 \\
(67 \%) \\
\end{array}$ & Agreed \\
\hline PF4 & $\begin{array}{l}\text { Lack of value for education demonstrated } \\
\text { by parents }\end{array}$ & $\begin{array}{c}64 \\
(21 \%)\end{array}$ & $\begin{array}{c}12 \\
(4 \%)\end{array}$ & $\begin{array}{c}203 \\
(67 \%)\end{array}$ & $\begin{array}{c}23 \\
(8 \%)\end{array}$ & Agreed \\
\hline PF5 & Father's or mother's death & $\begin{array}{c}20 \\
(7 \%)\end{array}$ & $\begin{array}{c}8 \\
(3 \%) \\
\end{array}$ & $\begin{array}{c}70 \\
(23 \%)\end{array}$ & $\begin{array}{c}202 \\
(67 \%)\end{array}$ & Agreed \\
\hline PF6 & Parents with financial difficulties & $\begin{array}{c}7 \\
(2 \%) \\
\end{array}$ & $\begin{array}{c}23 \\
(8 \%)\end{array}$ & $\begin{array}{c}120 \\
(40 \%)\end{array}$ & $\begin{array}{c}152 \\
(50 \%)\end{array}$ & Agreed \\
\hline
\end{tabular}

Source: Authors' own study.

Results presented in Table 4 show that respondents supported the statement (78 respondents agreed) that over pampering leads to students' deviant behavior, while majority of the respondents concurred (224 respondents strongly agreed) that over pampering of children by parent causes a student to exhibit deviant behavior in school. Most of the respondents also agreed that rejection of children by parents ( 290 respondents strongly agreed) and parents' separation (204 respondents strongly agreed) result in students' maladaptive behaviors. Similarly, the results presented in Table 4 revealed that lack of value for education demonstrated by parents is one of the factors responsible for students' indiscipline in school (203 respondents agreed). In addition, it was revealed that most of the respondents agreed (202 respondents strongly agreed) with the statement that father's or mother's death leads to students' misbehavior, whereas 152 respondents strongly agreed with the statement that parents with financial difficulties often make students involve in all kinds of deviant behaviors.

\begin{tabular}{|c|c|c|c|c|c|c|}
\hline & Item & SD & D & A & SA & Remark \\
\hline SF1 & Poor value system & $\begin{array}{c}20 \\
(7 \%)\end{array}$ & $\begin{array}{c}27 \\
(8 \%)\end{array}$ & $\begin{array}{c}102 \\
(34 \%)\end{array}$ & $\begin{array}{c}153 \\
(51 \%) \\
\end{array}$ & Agreed \\
\hline SF2 & Injustice in the society & $\begin{array}{c}5 \\
(2 \%) \\
\end{array}$ & $\begin{array}{c}7 \\
(2 \%)\end{array}$ & $\begin{array}{c}10 \\
(3 \%)\end{array}$ & $\begin{array}{c}280 \\
(93 \%)\end{array}$ & Agreed \\
\hline SF3 & Unwholesome mass media & $\begin{array}{c}- \\
(0 \%)\end{array}$ & $\begin{array}{c}- \\
(0 \%)\end{array}$ & $\begin{array}{c}128 \\
(42 \%)\end{array}$ & $\begin{array}{c}174 \\
(58 \%)\end{array}$ & Agreed \\
\hline SF4 & Peer influence & $\begin{array}{c}- \\
(0 \%) \\
\end{array}$ & $\begin{array}{c}- \\
(0 \%) \\
\end{array}$ & $\begin{array}{c}124 \\
(41 \%) \\
\end{array}$ & $\begin{array}{c}178 \\
(59 \%)\end{array}$ & Agreed \\
\hline SF5 & $\begin{array}{l}\text { Lack of preaching about good deeds } \\
\text { by religious leaders }\end{array}$ & $\begin{array}{c}12 \\
(4 \%)\end{array}$ & $\begin{array}{c}50 \\
(17 \%)\end{array}$ & $\begin{array}{c}220 \\
(73 \%)\end{array}$ & $\begin{array}{c}20 \\
(6 \%)\end{array}$ & Agreed \\
\hline
\end{tabular}

Source: Authors' own study.
Teachers'

Perceived

Factors of

Deviant

Behavior among

Secondary

School Students

in Kwara State: Implication for

Educational

Managers

Table 4.

Parent factor
Table 5.

Societal factor 


\section{IJSR} 7

Results in Table 5 indicate that societal factors contribute to deviant behavior among students in secondary school as agreed by the majority of the respondents. One hundred and fifty-three respondents strongly agreed with the statement that poor value system contributes to deviant behavior. With regard to social injustice, 280 respondents strongly agreed with the fact that it leads to maladaptive behavior, and 174 respondents were of the same opinion as far as the unwholesome mass media is concerned. In the same vein, the statement that peer influence contributed to students' deviant behavior was shared by 178 respondents, whereas the fact of no preaching about good deeds by religious leaders as a factor which leads to such behaviors received 220 positive responses. Therefore, it can be said that the foregoing student factor is responsible for students' involvement in behaviors that are not in line with school rules and regulations.

Table 6.

School factor

\begin{tabular}{|c|c|c|c|c|c|c|}
\hline & Item & SD & D & A & SA & Remarl \\
\hline SF1 & Strict school rules and regulations & $\begin{array}{c}- \\
(0 \%) \\
\end{array}$ & $\begin{array}{c}- \\
(0 \%) \\
\end{array}$ & $\begin{array}{c}120 \\
(40 \%)\end{array}$ & $\begin{array}{c}182 \\
(60 \%)\end{array}$ & Agreed \\
\hline SF2 & Unconducive school environment & $\begin{array}{c}2 \\
(1 \%)\end{array}$ & $\begin{array}{c}10 \\
(3 \%)\end{array}$ & $\begin{array}{c}70 \\
(23 \%)\end{array}$ & $\begin{array}{c}220 \\
(73 \%)\end{array}$ & Agreed \\
\hline SF3 & Lack of extracurricular activities & $\begin{array}{c}17 \\
(6 \%)\end{array}$ & $\begin{array}{c}3 \\
(1 \%)\end{array}$ & $\begin{array}{c}180 \\
(60 \%)\end{array}$ & $\begin{array}{c}102 \\
(33 \%)\end{array}$ & Agreed \\
\hline SF4 & Poor teaching performed by some teachers & $\begin{array}{c}26 \\
(9 \%) \\
\end{array}$ & $\begin{array}{c}3 \\
(1 \%)\end{array}$ & $\begin{array}{c}168 \\
(55 \%)\end{array}$ & $\begin{array}{c}106 \\
(35 \%)\end{array}$ & Agreed \\
\hline SF5 & Teachers' lateness and absenteeism & $\begin{array}{c}- \\
(0 \%) \\
\end{array}$ & $\begin{array}{c}- \\
(0 \%) \\
\end{array}$ & $\begin{array}{c}208 \\
(69 \%) \\
\end{array}$ & $\begin{array}{c}94 \\
(31 \%) \\
\end{array}$ & Agreed \\
\hline SF6 & Overcrowded classroom & $\begin{array}{c}- \\
(0 \%) \\
\end{array}$ & $\begin{array}{c}- \\
(0 \%) \\
\end{array}$ & $\begin{array}{c}124 \\
(41 \%) \\
\end{array}$ & $\begin{array}{c}178 \\
(59 \%)\end{array}$ & Agreed \\
\hline SF7 & Poor study habit & $\begin{array}{c}47 \\
(16 \%)\end{array}$ & $\begin{array}{c}35 \\
(12 \%)\end{array}$ & $\begin{array}{c}102 \\
(34 \%)\end{array}$ & $\begin{array}{c}118 \\
(38 \%)\end{array}$ & Agreed \\
\hline SF8 & Students' restlessness & $\begin{array}{c}- \\
(0 \%) \\
\end{array}$ & $\begin{array}{c}- \\
(0 \%) \\
\end{array}$ & $\begin{array}{c}234 \\
(77 \%)\end{array}$ & $\begin{array}{c}68 \\
(23 \%)\end{array}$ & Agreed \\
\hline SF9 & $\begin{array}{l}\text { Poor leadership of some school } \\
\text { administrators }\end{array}$ & $\begin{array}{c}65 \\
(22 \%) \\
\end{array}$ & $\begin{array}{c}37 \\
(12 \%) \\
\end{array}$ & $\begin{array}{c}120 \\
(40 \%) \\
\end{array}$ & $\begin{array}{c}80 \\
(26 \%) \\
\end{array}$ & Agreed \\
\hline SF10 & Emotional instability & $\begin{array}{c}30 \\
(10 \%) \\
\end{array}$ & $\begin{array}{c}11 \\
(4 \%) \\
\end{array}$ & $\begin{array}{c}157 \\
(52 \%) \\
\end{array}$ & $\begin{array}{c}102 \\
(34 \%)\end{array}$ & Agreed \\
\hline SF11 & Poor academic performance & $\begin{array}{c}- \\
(0 \%)\end{array}$ & $\begin{array}{c}- \\
(0 \%)\end{array}$ & $\begin{array}{c}104 \\
(34 \%)\end{array}$ & $\begin{array}{c}198 \\
(66 \%)\end{array}$ & Agreed \\
\hline
\end{tabular}

Source: Authors' own study.

The research results in Table 6 reveal that majority of the respondents agreed that strict school rules and regulations lead to deviant behavior among secondary school students (182 respondents strongly agreed, 120 respondents agreed). As for unconducive school environment, 220 respondents strongly agreed and 70 respondents agreed with the statement that it is a school-based factor of deviant behavior among students in secondary schools. Also, lack of extracurricular activities was perceived as such a factor by 180 (agreed) and 102 (strongly agreed) respondents, indicating that it is responsible for deviant behavior. Similarly, 168 respondents agreed and 106 respondents strongly 
agreed with regard to poor teaching performed by some teachers as it contributes to deviant behavior among students, while in case of teachers' lateness and absenteeism, such an opinion is shared by 208 (agreed) and 94 (strongly agreed) respondents. Also, overcrowded classroom contributes to students' maladaptive behavior (124 agreed, 178 respondents strongly agreed) and similarly, poor study habit (102 agreed, 118 strongly agreed). Furthermore, students' restlessness is also a school-based factor that leads to the above-mentioned behavior (234 respondents agreed, 68 respondents strongly agreed). The same opinion is shared in case of poor leadership of some schools (120 respondents agreed, 80 respondents strongly agreed). The research result concerning the last two school-based factors presented in Table 6 reveal that emotional instability and poor academic performance are perceived as factors leading to students' deviant behavior (157 respondents agreed, 102 respondents strongly agreed, and 104 respondents agreed, 198 respondents strongly agreed, respectively).

Research Question No. 2: What are the measures that can be used to reduce deviant behavior among students?

\begin{tabular}{|c|c|c|c|c|c|c|}
\hline $\mathrm{S} / \mathrm{N}$ & Item & SD & D & A & SA & Remark \\
\hline RD1 & Moral leadership and education & $(\%)$ & $(\%)$ & $\begin{array}{c}204 \\
(68 \%)\end{array}$ & $\begin{array}{c}98 \\
(32 \%)\end{array}$ & Agreed \\
\hline RD2 & School authorities as good models & $(\%)$ & $(\%)$ & $\begin{array}{c}48 \\
(16 \%)\end{array}$ & $\begin{array}{c}254 \\
(84 \%) \\
\end{array}$ & Agreed \\
\hline RD3 & $\begin{array}{l}\text { Provision of adequate facilities for teaching, } \\
\text { games and sports }\end{array}$ & 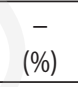 & $\begin{array}{c}- \\
(\%)\end{array}$ & $\begin{array}{c}140 \\
(46 \%) \\
\end{array}$ & $\begin{array}{c}162 \\
(54 \%)\end{array}$ & Agreed \\
\hline RD4 & Emphasis on extracurricular activities & $\begin{array}{c}2 \\
(1 \%) \\
\end{array}$ & $\begin{array}{c}8 \\
(3 \%) \\
\end{array}$ & $\begin{array}{c}140 \\
(46 \%) \\
\end{array}$ & $\begin{array}{c}152 \\
(50 \%) \\
\end{array}$ & Agreed \\
\hline RD5 & Reduction in class size & $\begin{array}{c}- \\
(0 \%) \\
\end{array}$ & $\begin{array}{c}- \\
(0 \%) \\
\end{array}$ & $\begin{array}{c}92 \\
(30 \%) \\
\end{array}$ & $\begin{array}{c}210 \\
(70 \%)\end{array}$ & Agreed \\
\hline RD6 & Value re-orientation & $\begin{array}{c}- \\
(0 \%) \\
\end{array}$ & $\begin{array}{c}- \\
(0 \%) \\
\end{array}$ & $\begin{array}{c}32 \\
(11 \%) \\
\end{array}$ & $\begin{array}{c}270 \\
(89 \%)\end{array}$ & Agreed \\
\hline RD7 & Effective parent-teacher association (PTA) & $\begin{array}{c}4 \\
(1 \%) \\
\end{array}$ & $\begin{array}{c}10 \\
(3 \%) \\
\end{array}$ & $\begin{array}{c}190 \\
(64 \%) \\
\end{array}$ & $\begin{array}{c}98 \\
(32 \%) \\
\end{array}$ & Agreed \\
\hline RD8 & Positive teacher/students relationship & $\begin{array}{c}22 \\
(7 \%) \\
\end{array}$ & $\begin{array}{c}14 \\
(5 \%) \\
\end{array}$ & $\begin{array}{c}170 \\
(56 \%) \\
\end{array}$ & $\begin{array}{c}96 \\
(32 \%) \\
\end{array}$ & Agreed \\
\hline RD9 & Frequent counseling services & $\begin{array}{c}- \\
(0 \%) \\
\end{array}$ & $\begin{array}{c}- \\
(0 \%) \\
\end{array}$ & $\begin{array}{c}104 \\
(44 \%) \\
\end{array}$ & $\begin{array}{c}198 \\
(66 \%) \\
\end{array}$ & Agreed \\
\hline RD10 & Use of punishment & $\begin{array}{c}32 \\
(10 \%)\end{array}$ & $\begin{array}{c}50 \\
(17 \%) \\
\end{array}$ & $\begin{array}{c}100 \\
(33 \%)\end{array}$ & $\begin{array}{c}120 \\
(40 \%)\end{array}$ & Agreed \\
\hline
\end{tabular}

Source: Authors' own study.

As displayed in Table 7, results show 12 measures that can be used to reduce deviant behavior among students in secondary schools as suggested by the majority of the respondents. The measures include: moral leadership and education (204 respondents agreed and 98 respondents strongly agreed); school authorities as role models (48 respondents agreed and 254 respondents strongly agreed); provision of adequate
Teachers'

Perceived

Factors of

Deviant

Behavior among Secondary School Students in Kwara State: Implication for Educational Managers

Table 7.

Measures of reducing deviant behavior 
IJSR

7

facilities (140 respondents agreed and 162 respondents strongly agreed); emphasis on extracurricular activities (140 respondents agreed and 152 respondents strongly agreed). In addition, among the measures that can be used to minimize deviant behavior there were also: reduction in class size (92 respondents agreed and 210 respondents strongly agreed); value re-orientation (32 respondents agreed and 270 respondents strongly agreed); effective communication between parents and teachers (190 respondents agreed and 98 respondents strongly agreed); positive teacher and students' relationship (170 respondents agreed and 96 respondents strongly agreed); frequent counseling services (104 respondents agreed and 198 respondents strongly agreed) and use of punishment with 100 respondents who agreed and 120 respondents who strongly agreed with the statement that such measures could reduce deviant behaviors among students.

Research Question No. 3: Is there any significant difference in perception of deviant behavior based on teachers 'religion, age and educational qualification?

\section{Hypothesis 1:}

There is no significant difference in teachers' perception of deviant behaviors based on religious affiliation.

\section{Table 8.}

ANOVA result comparing the respondents' perception of prevention of deviant behaviors on the basis of religious affiliation

\section{Table 9.}

Duncan's Multiple Range Test (DMRT) showing the direction of significant difference

\begin{tabular}{lccccc}
\hline Source of variable & Df & Sum of squares & Mean squares & $\begin{array}{c}\text { Calculated } \\
\text { F-ratio }\end{array}$ & $\begin{array}{c}\text { Critical } \\
\text { F-ratio }\end{array}$ \\
\cline { 1 - 4 } Between groups & 2 & 454.49 & 22.172 & & \multirow{2}{*}{$5.18^{*}$} \\
\cline { 1 - 4 } Within groups & 300 & 2617.76 & 43.81 & & \\
\cline { 1 - 4 } Total & 302 & 3072.25 & & & \\
\hline
\end{tabular}

Source: Authors' own study.

* significant level, $\mathrm{p}<0.05$

In Table 8 , it is revealed that the calculated F-ratio of 5.18 is greater than the critical F-ratio of 3.00. Since the calculated F-ratio is greater than the critical F-ratio, the hypothesis which stated that there is no significant difference in the perception of teachers on deviant behavior based on religious affiliation was rejected because a significant difference was found.

\begin{tabular}{cccc}
\hline Group & Value & $\mathbf{X}$ (mean) & Count \\
\hline 2 & Islam & 46.86 & 160 \\
\hline 1 & Christianity & 45.78 & 142 \\
\hline
\end{tabular}

Source: Authors'own study.

The result of DMRT indicated that group 2, which has a mean score of 46.86 , significantly differed from group 1 whose mean score is 45.78 . 


\section{Hypothesis 2:}

There is no significant difference in teachers' perception of deviant behaviors based on age.

\begin{tabular}{|c|c|c|c|c|c|}
\hline Source & Df & Sum of squares & Mean squares & $\begin{array}{c}\text { Calculated } \\
\text { F-ratio }\end{array}$ & $\begin{array}{l}\text { Critical } \\
\text { F-ratio }\end{array}$ \\
\hline Between groups & 2 & 631.030 & 31.552 & \multirow{3}{*}{$7.11^{*}$} & \multirow{3}{*}{3.00} \\
\hline Within groups & 300 & 13616.14 & 34.01 & & \\
\hline Total & 302 & 14247.17 & & & \\
\hline
\end{tabular}

Source: Authors' own study.

* significant level, $\mathrm{p}<0.05$

The analysis from Table 4 showed that the calculated F-value (7.11) is greater than the critical F-ratio (3.00). It revealed that the null hypothesis, which states that there is no significant difference in the perception of teachers based on their age, is rejected; $\mathrm{F}(\mathrm{df}=2 \& 300)=7.11, \mathrm{p}<0.05$.

\begin{tabular}{|c|c|c|c|}
\hline Group & Value & $X$ (mean) & Count \\
\hline 1 & $20-35$ years old & 48.82 & 145 \\
\hline 2 & 36 years and above & 39.87 & 157 \\
\hline
\end{tabular}

Source: Authors' own study.

The result of DMRT indicated that group 1, with a mean score of 48.82 differed significantly from group 2 whose mean score is 39.87 .

\section{Hypothesis 3:}

There is no significant difference in teachers' perception of deviant behaviors based on educational qualification.

\begin{tabular}{|c|c|c|c|c|c|}
\hline Source & Df & Sum of squares & Mean squares & $\begin{array}{c}\text { Calculated } \\
\text { F-ratio }\end{array}$ & $\begin{array}{l}\text { Critical } \\
\text { F-ratio }\end{array}$ \\
\hline Between groups & 2 & 531.30 & 31.552 & \multirow{3}{*}{$6.11^{*}$} & \multirow{3}{*}{3.00} \\
\hline Within groups & 300 & 13616.12 & 34.01 & & \\
\hline Total & 302 & 14147.42 & & & \\
\hline
\end{tabular}

Source: Authors' own study.

* significant level, $\mathrm{p}<0.05$

Table 12 revealed the result of the ANOVA showing that the calculated F-value (6.11) is greater than the critical F-ratio (3.00), hence, the null hypothesis, which states that there is no significant difference in the perception of teachers based on educational qualification, is rejected; $\mathrm{F}(\mathrm{df}=2 \& 300)=6.11, \mathrm{p}<0.05$.
Teachers'

Perceived

Factors of

Deviant

Behavior among

Secondary...

Table 10.

ANOVA result comparing the respondents' perception of prevention of deviant behavior on the basis of age

Table 11. DMRT showing the direction of significant difference

Table 12. ANOVA result comparing the respondents' perception of prevention of deviant behaviors on the basis of educational qualifications 


\section{IJSR 7}

Table 13. DMRT showing the direction of significant difference

\begin{tabular}{lccc}
\hline Group & Value & $\mathbf{X}$ (mean) & Count \\
\hline 1 & OND, NCE and equivalence & 38.50 & 182 \\
\hline 2 & First degree, HND and above & 37.59 & 120 \\
\hline
\end{tabular}

Note: OND - Ordinary National Diploma; NCE - National Certificate in Education; HND - Higher National Diploma

Source: Authors' own study.

The DMRT showed that group 1, which has a mean score of 38.50, significantly differed from group 2 with a mean score of 37.59 .

\section{Discussion}

The discussion is based on research questions and objectives formulated for the study. The first research question was: What are the factors responsible for deviant behavior among students? In line with the first research question, the first research objective was to identify possible factors responsible for deviant behavior among students. Thus, the findings of the present study revealed three factors that are responsible for students' behavior, they are: parent factor, societal factor and school factor. With regard to the parent factor, our analysis indicated that over pampering of children by parents, rejection of children by parents and parents' separation lead to students' maladaptive behavior. We also found that lack of value for education demonstrated by parents and father's or mother's death make students exhibit deviant behavior. Our research results are in line with the study conducted by Reid (1999) who reported that students with poor background involved in truancy and other form of behavior in school. The results are also in consonance with the study conducted by Gray and Jesson (1990) who found that students from single-parent families have poorer attendance rate than those from the complete family. Our finding agrees with the work of Siziya et al. (2007) who reported that some parents rarely checked homework or they neither understood the difficulties and concerns of students nor supervised them. Our finding finds confirmation in the research conducted by Omoegun (1995), Osarenren (1996), and Owodunni (2008) who concluded that children from aggressive home environment would rather prefer to spend most of his/her days in the midst of his/her peers where he/she would be happier and more relaxed. Furthermore, our analysis indicates that parents with financial difficulties are responsible for student unacceptable behaviors such as stealing. The findings corroborate the study of Siziya et al. (2007) who concluded that many students go hungry sometimes because of lack of food at home. This, in turn, often results in truancy, a situation in which students miss class because they need an opportunity to fend for themselves. According to Garry (2001), insufficiencies in the home and lack of capacity to make petty cash to augment family income as well as unfavorable home conditions cause truancy. Our finding is also in line with the studies conducted by BoluSteve and Esere (2017) and Osarenren (1996) who concluded that deviant behavior is caused by lack of effective parental upbringing.

With regard to the societal factor, our study revealed that poor value system, injustice in the society and unwholesome mass media contribute to students' deviant behavior. Our research results showed that peer influence and lack of preaching about 
good deeds by religious leaders cause students' deviant behaviors such as smoking, cultism, Internet scam, raping, lateness, idleness, vandalism, bullying, etc. In agreement with the foregoing finding is the study by Yarduma and Abdulamid (2007) who found that the dynamic explosion of the media system through Facebook, Twitter, LinkedIn, WhatsApp, Imo, YouTube, television, radio, magazines and newspapers have contributed to the inculcation of deviant practices among students in school. Nowadays, the majority of students spend too much time on social media, which definitely has a negative impact on their lives. The finding also concurs with Danso (2010) who noted that some programs which are broadcast on radio and television usually promote violence and pornography among students. The study is also consistent with the study of Ponfua (2015) who found that unwholesome mass media was responsible for students' disobedient conducts in secondary schools. The finding is also supported by the social learning theory, which postulates that family and peer relationships exert a significant influence on adolescent alcohol use as they constitute the primary institutions where good or bad morals are learned. It also emphasizes the importance children or adolescents place on their friends as they reach adulthoods and gradually gain freedom from their parents (Akers, 1998; Akers and Sellers, 2004; Akers and Jensen, 2005). The finding is also in line with Sigmund Freud's psychological theory which suggests that when a child is not well socialized, he/ she can develop antisocial behavior instincts and when such deviant attitudes get fixed at any of the psychosocial stages, such an individual can engage in deviant behavior. Freud stressed the importance of early years of childhood fixation in defining the adult personality (Omotosho, 2009).

As for the school factor, our finding revealed that strict school rules and regulations, unconducive school environment, lack of extra-curricular activities, poor teaching performed by some teachers, lateness and absenteeism demonstrated by teachers and overcrowded classrooms are responsible for deviant behavior among secondary schools students. The finding is in consonance with the study conducted by Ponfua (2015) who found that school-based factor was responsible for students' deviant behaviors such as teachers' lateness and absenteeism in class, overcrowded classrooms, unconducive school environment, unenforceable school rules and regulations, poor teaching and poor leadership by school administrators. The finding is in support of Asiyai (2005) and Osarenren (1996) who reported that unconducive school environment characterized by an acute shortage of facilities for teaching, games and sports, engendered unrest and crippled academic activities and resulted in students' unacceptable behaviors in school. Owodunni (2008) and Yaroson (2006) reported that unrealistic school rules were the causes of indiscipline and concluded that rules and regulations are meant to guide and control activities in school but when they become too much and unenforceable, they tend to breed misbehavior. In the same vein, studies conducted by Rothman (2001) and Oyesola (2002) agree with the present study results on unconducive school environment. Furthermore, our study found that poor study habit, students' restlessness, poor leadership of some school administrators, emotional instability and poor academic performance are responsible for students' deviant behavior. The finding is supported by the study conducted by Iheanyi and Ikechi (2012) and Ponfua (2015) who concluded that students' emotional instability was responsible for deviant behavior such as truancy in secondary school.
Teachers'

Perceived

Factors of

Deviant

Behavior among

Secondary

School Students

in Kwara State:

Implication for

Educational

Managers 
IJSR 7

The second research question was: What are the measures that can be used to reduce deviant behavior among students? In line with the second research question, the second research objective was to provide measures that can be used to reduce deviant behavior among secondary schools students. Our findings reveal ten measures which can be used to reduce deviant behavior in secondary schools. The measures include provision of moral leadership and education, need for school authorities to be role models for students, provision of adequate facilities for teaching, games and sports and emphasis on extracurricular activities. Our findings showed that reduction in class size, value reorientation, as well as establishment of an effective parent-teacher association (PTA), are measures that can be used to minimize deviant behavior among students. In addition, our results indicate that positive teacher/students relationship, frequent counseling services and use of punishment are effective measures that can be implemented to reduce deviant behavior. The above-mentioned measures support the study of Asonibare (2016) who concluded that punishment can be used in reducing deviant behavior in school. Punishment refers to the use of aversive stimuli to decrease undesirable behavior and it is often used when all other techniques have failed. He opined that two major types of punishment: positive punishment (when the counselor applies aversive consequences like kneeling down and flogging) and negative punishment (this involves the withdrawal of certain privileges) can be used to significantly reduce deviant behavior in school. The finding is also in consonance with the work of Salami and Aremu (2006) who explains that punishment that will be used to reduce deviant behavior in school must be retributive; it should serve as a deterrent and must be reformative and that punishment should be applied immediately after a negative behavior. Also, Sulaiman (2011) who explains that school counselors should help students improve their wellbeing, alleviate distress, resolve crises and apply counseling strategies in order to correct maladjusted behavior among students. The findings of the current study also support the earlier study conducted by Bolu-Steve and Esere (2017) who said that students need to be assisted in handling contemporary challenges and that information-based intervention is an effective strategy in handling deviant behavior, so counselors should always provide right information to in-school adolescents about the negative effects of deviant behaviors. The finding is also in line with the study of Ponfua (2015) who suggests effective strategies that can be used to reduce deviant behaviors. They include positive teacher-students relationship, availability of facilities and effective supervision.

The third research question was: Is there any significance difference in perception of deviant behavior based on teachers' religion, age and educational qualification? The third research objective of the study was to know if there was a significant difference in perception of perceived behavior based on teachers' religion, age and educational qualification. In order to answer the research questions and objectives, three hypotheses were formulated and tested. The first hypothesis stated that there was no significant difference in teachers' perception of deviant behaviors based on religious affiliation. Our findings confirm that there is a significant difference (the calculated F-ratio of 5.18 was greater than the critical F-ratio of 3.00.) in teachers' perception of deviant behavior based on their religious affiliation. The second hypothesis stated that there was no significant difference in teachers' perception of deviant behaviors based on age. The present findings confirm that there is a significant difference (calculated F-value 7.11 is 
greater than the critical F-ratio 3.00) in teachers' perception of deviant behavior based on their age. Lastly, the third hypothesis stated that was no significant difference in teachers' perception of deviant behaviors based on educational qualification. Our research results revealed that there is a significance difference (calculated F-value 6.11 is greater than the critical F-ratio 3.00) in teachers' perception of deviant based on their educational qualification. The findings is in congruent with the study of Bolu-Steve and Esere (2017) who found that the experience of the counselors differ in terms of an appropriate strategy for managing deviant behavior among in-school adolescents irrespective of their years of service, religion and school type. The gender of the counselor tends to modify the strategies applied in the management of deviant behavior among in-school adolescents.

\section{Implication of findings for educational managers}

Based on the study results, there are some implications for educational managers in school. Firstly, educational managers should take cognizance of the fact that deviant behavior is a general phenomenon cutting across all levels of education (primary, secondary and tertiary) and that three factors (parent factor, societal factor and school factor) cause student' maladaptive behaviors. Secondly, measures such as effective punishment and rules and regulations should be implemented to stem the unwholesome behaviors of students in schools. Thirdly, an effort should be made by educational managers to make students' parents aware of the fact that they need to play an active role in correcting the attitude of their children. Fourthly, since school counselors are under the supervision of educational managers, educational managers should provide an enabling environment for counselors to carry out their counseling duties so as to meet students' behavioral challenges. Additionally, educational managers should take note of the following:

1. School counselors should focus more on behaviors of students, apart from paying more attention to learning subject-matter in schools alone.

2. While handling the problem of students' behaviors, solving procedures should be adopted and taught by the counselors/psychologists so that students could handle other academic problems as well as other deviant behaviors.

3. School counselors need to cooperate with teachers in reaching out to the society through religious programs. This could be done by preaching and campaigns in religious centers.

4. Counselors should consider students' socio-economic factors such as parents' financial difficulties, students' broken home, etc. when offering counseling to students.

\section{Conclusions}

Based on the findings, it has been established that three main factors (parent, societal and school) are responsible for students' deviant behavior as expressed by teachers. It can be said that deviant behavior is antithetical to students' learning and bad omen for the development of the school. Therefore, effective measures suggested in the study should be used to reduce deviant behaviors such as cultism, truancy, examination malpractice, drug abuse, bullying, stealing, etc. Taken together, our study has successfully provided answers to the three research questions and the three research objectives have been
Teachers'

Perceived

Factors of

Deviant

Behavior among

Secondary

School Students

in Kwara State:

Implication for

Educational

Managers 
IJSR 7

achieved. Therefore, this study contributes to the body of knowledge in three ways (practically, theoretically and methodologically). From the practical perspective, the findings of the study will be useful to educational managers and other stakeholders (e.g. government, parents, traditional rulers, non-governmental organizations (NGOs), etc.) in education on how to identify and manage deviant behaviors among secondary schools students. From the theoretical perspective, the research results of the present study validate the social learning theory, which postulates that peers exert a significant influence on an individual who learns to take alcohol or drugs in small and informal groups. Similarly, this study validates Sigmund Freud's psychological theory, which suggests that a child that is not well socialized can develop antisocial behavior instincts and when such a child gets fixated at any of the psychosocial stages, such an individual can engage in deviant behavior. Furthermore, our study contributes methodologically to the body of knowledge in two ways. Firstly, this study adapted instrument from the studies conducted by Iheanyi and Ikechi (2012) and Ponfua (2015) to investigate the teachers' perceived deviant behavior among students in secondary schools in Kwara State. Secondly, the psychometric properties of the items in the adapted instrument were assessed using Partial Least Square (PLS) software to ensure adequate loadings of the items, which exceeded .40 minimum loading as suggested by researchers.

\section{Future research direction}

Firstly, since this study investigated teachers' perceived factors of deviant behavior in secondary schools via the quantitative approach and found that three factors (parent, societal and school) cause deviant behavior among students, an additional study is needed to investigate it via a qualitative approach so that a detailed explanation of the factors can be understood. Secondly, in the future, researchers could use mixed-method approaches (a combination of quantitative and qualitative approach) to investigate deviant behavior. Thirdly, the scope of the present study was limited to the Ilorin metropolis area of Kwara State, hence, additional studies are needed in other zones (Kwara South and Kwara North) so as to know whether similar findings will be found or not. Lastly, in order to collect scientific data, this study used only teachers as respondents; therefore, future studies should include students as well.

\section{References}

Akers, R.L. (1998), Social Learning and Social Structure: A General Theory of Crime and Deviance, Northeastern University Press, Boston, MA.

Akers, R.L., and Jensen, G.F. (2005), "Empirical status of social learning theory of crime and deviance: The past, present, and future", in: F.T. Cullen, J.P. Wright, K.R. Blevins (eds.), Advances in Criminological Theory, vol. 15, Transaction Publishers, Piscataway, NJ, pp. 37-76.

Akers, R.L., and Sellers, C.S. (2004), Criminological Theories: Introduction, Evaluation, and Application, Roxbury Publishing Los Angeles, CA.

Akseer, T., Bosacki, S.L., Rose-Krasnor, L., and Coplan, R.J. (2014), "Canadian elementary school teachers' perceptions of gender differences in shy girls and boys in the classroom", Canadian Journal of School Psychology, vol. 29, no. 2, pp. 100-115.

Asiyai, R.I. (2005), Trade union disputes and their perceived impacts on the University in Nigeria, unpublished doctoral thesis, Delta State University, Abraka. 
Asonibare, J.B. (2016), Modifying Maladaptive Behavior in Schools. Guidance and Counselling in Education, University Press, Ilorin.

Bolu-Steve, F.N., and Esere, M.O. (2017), "Strategies for managing deviant behavior among inschool adolescents as expressed by secondary school counsellors in Kwara State", Inkanyiso Journal of Humanities and Social Sciences, vol. 9, no. 1, pp. 87-98.

Boyd, J.L. (2015), National institute on drug abuse, brains and behavior, available at: http://www. livestrong.com/disease_and_conditions (accessed: 3 June 2015).

Cluver, L., Bowes, L., and Gardner, F. (2010), "Risk and protective factors for bullying victimization among AIDS-affected and vulnerable children in South Africa", Child Abuse \& Neglect, vol. 34 , no. 10 , pp. 793-803.

Creswell, J. (2009), Research Design: Qualitative, Quantitative, and Mixed Methods Approaches, Sage Publications, USA.

Creswell, J.W., and Clark, V.L.P. (2007), Designing and Conducting Mixed Methods Research, Sage Publications, Thousand Oaks, CA.

Duarte, P., and Raposo, M. (2010), "A PLS model to study brand preference: An application to the mobile phone market", in: V. Esposito Vinzi, W.W. Chin, J. Henseler, H. Wang (eds.), Handbook of Partial Least Squares, Springer, Berlin-Heidelberg, pp. 449-485.

Dyregrov, A., Dyregrov, K., and Idsoe, T. (2013), “Teachers' perceptions of their role facing children in grief", Emotional and Behavioural Difficulties, vol. 18, no. 2, pp. 125-134.

Efstratopoulou, M.A., Janssen, R., and Simons, J. (2012), "Children's deviant behavior in primary education: Comparing physical educator's implicit theory with diagnostic criteria”, Journal of Attention Disorders, DOI: 1087054712449479.

Esere, M.O. (2008), Effect of sex education programme on at-risk sexual behavior of school-going adolescents in Ilorin, Nigeria. African Health Sciences, vol. 8, no. 2, pp. 120-125. Retrieved December 19, 2017 from: http://www.bioline.org.br/abstract?id=hs08026\&lang=en

Espelage, D.L., Polanin, J.R., and Low, S.K. (2014), "Teacher and staff perceptions of school environment as predictors of student aggression, victimization, and willingness to intervene in bullying situations", School Psychology Quarterly, vol. 29, no. 3, pp. 287-305.

Estévez, E., Musitu, G., and Herrero, J. (2005), "The influence of violent behaviour and victimization at school on psychological distress: The role of parents and teachers", Adolescence, vol. 40, no. 157 , pp. $183-196$.

Garry, E.N. (2001). Truancy: First Step in a Lifetime of Problems, Official Bulletin of Juvenile, Justice and Delinquency Prevention. Washington: Office of Juvenile Justice and Delinquency Prevention, United States Department of Justice.

Gray, J., and Jesson, M. (1990), "Truancy in secondary schools amongst fifth year pupils", Links, vol. 15 , pp. $25-33$.

Hair, J.F., Sarstedt, M., Ringle, C.M., and Mena, J.A. (2012), “An assessment of the use of partial least squares structural equation modeling in marketing research", Journal of the Academy of Marketing Science, vol. 40, no. 3, pp. 414-433.

Helms, S.W., Choukas-Bradley, S., Widman, L., Giletta, M., Cohen, G.L., and Prinstein, M.J. (2014), "Adolescents misperceive and are influenced by high-status peers' health risk, deviant, and adaptive behavior", Developmental Psychology, vol. 50, no. 12, pp. 2697-2714.

Ibrahim, F.A. (2009), Teachers 'perception on the causes of deviant behavior among secondary school students in Ilorin East Local Government Area, unpublished B.Ed Thesis in the Department of Counsellor Education University of Ilorin, Nigeria.

Idowu, A.I. (2008), Prevalence of Smoking and Drug Use among Students in Ilorin Metropolis: Implications for Counselling, available at: http://www.google.com/articles (accessed: 2 October 2009).

Idris, O. (2016), Causes of deviant behavior among in-school adolescents in Lagos. Unpublished M.Ed Project Submitted to the Department of Educational Foundation, Lagos State University. 
IJSR 7

Iheanyi, N.O., and Ikechi, O.O. (2012), "Causes and levels of truancy among secondary school students: A case study of Rivers State, Nigeria", Problems of Education in the $21^{\text {st }}$ Century, vol. 45, pp. 51-62.

Jamiu, M.S. (2011), Causes and remedies of deviant behaviors, unpublished Master's thesis, University of Ilorin, Nigeria.

Malak, S., Deppeler, J.M., and Sharma, U. (2014), "Bangladeshi teachers' perceptions about student behaviour in primary schools", International Journal on School Disaffection, vol. 11, no. 1, pp. 59-78.

Ojedokun, O., Ogungbamila, A., and Kehinde, D. (2013), "Perception of parental bonding and tendency to perpetrate aggressive behaviour in a sample of Nigerian students", Frontiers, vol. 2 , no. 3, pp. 117-124.

Ojo, A.I. (2000), Strategies for improving guidance and counselling services as perceived by teachers and counsellors in secondary schools in Ogbomosho Metropolis. Unpublished B.Ed Project submitted to the Department of Counsellor Education University of Ilorin.

Ololube, N.P. (2013), "School safety and security: Concerns and forms of deviant behaviours and rejoinder to educational goals", International Journal of Education Economics and Development, vol. 4, no. 2, pp. 147-169.

Omoegun, M. (1995), The Adolescent and You, Mobolak Publishing Co., Lagos.

Omotosho, F. (2009), Relationship between boredom and deviant behavior among adolescents in Ilorin metropolis, unpublished B.Ed thesis in the Department of Counsellor Education University of Ilorin.

Orsati, F.T., and Causton-Theoharis, J. (2013), "Challenging control: Inclusive teachers' and teaching assistants' discourse on students with challenging behaviour", International Journal of Inclusive Education, vol. 17, no. 5, pp. 507-525.

Osarenren, N.A. (1996), “Absenteeism and truancy”, in: E.O. Obe (ed.), School Indiscipline and Remedies, Premier Press Publishers, Lagos.

Owodunni, A.A. (2008), "Prevalence of cigarette smoking behavior among school truants in Ijebu Ode, Ogun State, Nigeria: Implications for counseling", African Journal of Cross-Cultural Psychology and Sport Facilitation, vol. 10, pp. 170-181.

Owusu, A., Hart, P., Oliver, B., and Kang, M. (2010), “Association between bullying and psychological health among senior high school students in Ghana, West Africa", Journal of School Health, vol. 81, no. 5, pp. 231-238.

Oyerinde, O.O. (2004), Sports preference of secondary school student smokers and non-smokers in the South Western States of Nigeria. Department of Physical and Health Education, University of Ilorin, available at: http://www.com/articles (accessed: 9 April 2018).

Oyesola, G.O. (2002), "Discipline in schools", in: F. Durosaro, S. Ogunsaju (eds.), The Craft of Educational Management, Haytee Press and Publishing Co., Ilorin.

Pallant, J. (2010), SPSS Survival Manual: A Step-By-Step Guide To Data Analysis, Sage Publications, Thousand Oaks, CA

Pas, E.T., and Bradshaw, C.P. (2014), "What affects teacher ratings of student behaviors? The potential influence of teachers' perceptions of the school environment and experiences", Prevention Science, vol. 15, no. 6, pp. 940-950.

Ponfua, Y.N. (2015), "Students' indiscipline: types, causes and possible solutions: The case of secondary schools in Cameroon", Journal of Education and Practice, vol. 6, no. 22, pp. 64-73.

Primary school pupils protest sack of 21,780 teachers (2017), available at: http://www.pulse.ng/ communities/student/primary-school-pupils-protest-sack-of-21-780-teachers-video-id7568443. html (accessed: 9 April 2018).

Reid, K. (1999), Truancy and Schools, Routledge, London.

Richardson, N. (2014), Teachers' perceptions of resistant behaviour of children in the middle childhood developmental phase, doctoral dissertation, North-West University. 
Rothman, S. (2001), "School absence and students' background factors: A multilevel analysis", International Educational Journal, vol. 2, no. 1, pp. 59-68.

Ryan, A.M., and Shim, S.S. (2012), "Changes in help seeking from peers during early adolescence: Associations with changes in achievement and perceptions of teachers", Journal of Educational Psychology, vol. 104, no. 4, pp. 1122-1134.

Salami, S.O., and Aremu, A.O. (2006), Relationship between problem-solving ability and study behaviour among school-going adolescents in southwestern Nigeria, available at: https:// scholar.google.com/scholar?hl=en\&as_sdt $=0 \% 2 \mathrm{C} 5 \& \mathrm{q}=\mathrm{Salami} \% 2 \mathrm{C}+\mathrm{S} .+\mathrm{O} . \% 2 \mathrm{C}+\% 26+$ Are $\mathrm{mu} \% 2 \mathrm{C}+\mathrm{A} .+\mathrm{O} .+\% 282006 \% 29 .+$ Relationship + between + problemsolving + ability + and + stud $\mathrm{y}+$ behaviour+among + schoolgoing + adolescents $+\mathrm{in}+$ southwestern + Nigeria. + Retrieved $+\mathrm{xxx}$ $\mathrm{x}+\&$ btnG (accessed: 10 August 2018).

Sekaran, U., and Bougie, R. (2009), Research Methods for Business: A Skill Building Approach $\left(5^{\text {th }}\right.$ ed.), John Wiley \& Sons, UK.

Siziya, S., Muula, S., and Rudatsikira, E. (2007), "Prevalence and correlates of truancy among adolescents in Swaziland: Findings from the Global School-Based Health Survey", Child and Adolescent Psychiatry and Mental Health, vol. 1, pp. 1-15.

Sulaiman, J.M. (2011), Causes and remedies of deviant behavior among adolescents as expressed by teachers in Kwara State, unpublished M.Ed thesis in the Department of Counsellor Education University of Ilorin.

Ukwayi, J.K., Eja, O.F. and Unwanede, C.C. (2012), "Peer pressure and tobacco smoking among undergraduate students of the University of Calabar, Cross River State", Higher Education Studies, vol. 2, no. 3, pp. 92-101.

Vieno, A., Gini, G., Santinello, M., Lenzi, M., and Nation, M. (2011), "Violent behavior and unfairness in school: Multilevel analysis of Italian schools", Journal of Community Psychology, vol. 39 , no. 5 , pp. 534-550.

Worries as 30 killed in Ilorin cult clashes (2017), available at: https://thenationonlineng.net/worries30-killed-ilorin-cult-clashes (accessed: 9 April 2018).

Yarduma, A.C., and Abdulamid, Y.F. (2007), "A survey of behavior problems among secondary schools in Akwanga Local Government Area of Niger State", Journal of Arts Education, vol. 3, no. 1, pp. 11-19.

Yaroson, M.C. (2006), Strategies for curbing indiscipline in Nigeria secondary schools, available at: http://www.Accs.org.uk (accessed: 9 April 2018).

Zakaria, N., Reupert, A., and Sharma, U. (2013), "Malaysian primary pre-service teachers' perceptions of students' disruptive behaviour", Asia Pacific Education Review, vol. 14, no. 3, pp. 371-380. 